\title{
The Role of Green Practice as a Moderating Variable to Achieve Service Recovery Satisfaction
}

\author{
Luki Adiati Pratomo ${ }^{1}$, Dyah Astarini ${ }^{2}$, Darra Pradita Hidayat ${ }^{3}$, Aslih Abnuri ${ }^{4}$ \\ \{luki.adiati@trisakti.ac.id ${ }^{1}$, diah.astarini@trisakti.ac.id² \\ Universitas Trisakti, Jakarta, Indonesia
}

\begin{abstract}
This study investigated the influence of two service recovery strategies (apology and explanation) on recovery satisfaction. It also analyzed the role of green practice as a moderating variable on the influence of the two service recovery strategies on recovery satisfaction. The research design used was hypothesis testing. Research data was obtained from 40 respondents, collected using a non-probability method with a purposive sampling technique. The respondent criteria were environmentally-conscious hotel consumers who have experienced service failure in the last two years. Data analysis was done using multiple regression. The research results indicated that apology positively influenced service recovery satisfaction and green practice had a role as a moderating variable on the influence of explanation on service recovery satisfaction. Surprisingly, it turned out that explanation did not directly influence service recovery satisfaction, and green practice did not moderate the influence of apology on service recovery satisfaction.
\end{abstract}

Keywords: Green Practice; Apology; Explanation; Service Recovery Satisfaction

\section{Introduction}

Carrying out operational activities in an environmentally conscious manner has become important for the hotel industry in Indonesia (Erlangga, Rahmafitria, and Rosita, 2016; Setiawati and Sitorus, 2014) because consumers have begun to realize the importance of environmental management. As a result, this factor has become one of the considerations in choosing a hotel (Rosenbaum and Wong, 2015; Setiawati and Sitorus, 2014; Supriadi, 2016).

Unfortunately, environmentally-conscious hotels can also experience service failure. Indeed, this is sometimes unavoidable in service businesses even though the service providers try hard to reduce these failures in various ways. Several studies show that service businesses continuously try to improve their services, and pay attention to service dissatisfaction, service failures and consumer complaints problems (Blodgett, Bakir, Saklani, and Bachheti, 2015; Harun, Rokonuzzaman, Prybutok, and Prybutok, 2018; Heidenreich, Wittkowski, Handrich, and Falk, 2015). The company is even willing to spend a lot of money to fix the failures.

Service failure can drive consumers to convey a negative word of mouth, voice complaints and ultimately trigger consumers to switch to competitors (Moliner-Velázquez, Ruiz-Molina, and Fayos-Gardó, 2015). Therefore, service recovery is very important so that relationships 
with consumers can be improved (Azemi, Ozuem, Howell, and Lancaster, 2019; MolinerVelázquez et al., 2015), and it acts as a tool to build strong relationships between companies and customers (Ellyawati, Purwanto, and Dharmmesta, 2012).

Service failure handling can be carried out offline or online (Odoom, Agbemabiese, and Hinson, 2019). Therefore, it is very important to create a service recovery strategy to satisfy consumers with the improvements carried out (Azemi et al., 2019). It turns out that not only the recovery strategy can satisfy consumers, there are also moderating variables that can influence consumer satisfaction. These variables include the speed of response (Odoom et al., 2019), negative emotions (Ellyawati et al., (2012), the severity of failure (Weun, Beatty, and Jones (2004), relationship quality (Grégoire and Fisher, 2008), buyer-seller relationships (Chou, Hsu, and Goo, 2009) or culture (Wang and Mattila, 2011). Several other studies have also found that culture (Yani-de-Soriano et al., 2019) and perceived justice can moderate the influence of recovery strategy on consumer satisfaction (Harun, Rokonuzzaman, Prybutok, and Prybutok, 2019).

In every service failure, companies generally use several main strategies such as apology, compensation and explanation. These three strategies in various studies have resulted in different findings on the influence on consumer satisfaction (Heidenreich et al., 2015; Odoom et al., 2019; Siddiqui and Tripathi, 2010; Song, Sheinin, and Yoon, 2017). Gruber and Frugone (2011) found apology could be an important strategy in satisfying dissatisfied consumers, but it was less useful in other studies (Odoom et al., 2019). The role of explanation as a recovery strategy also generates different opinions.

Diverse opinions on the role of service improvement strategies give rise to the idea that the reasons why consumers are still not satisfied even though the company has tried to fix these failures need to be found. For this reason, moderating variables are needed because they have the possibility to strengthen or weaken the influence of service improvement strategies on customer satisfaction. One of the variables that can be a moderating variable to achieve customer satisfaction on service improvement is green practice. Today, consumers are becoming more concerned about the environment. As a result, their perceptions of companies that are environmentally conscious also increase. Companies that practice environmentallyconscious activities have an increasingly strong competitive advantage (Singjai, Winata, and Kummer, 2018). Green practice becomes one of the important factors to achieve customer satisfaction (Moser, 2015). In the hotel business, the role of green practice has become the reason consumers are loyal to the hotel (Assaker, 2020). It leads to the idea of the importance of green practice in conflict situations such as service failures.

Based on the above findings, this study aimed to measure the influence of apology and compensation on recovery satisfaction and the role of green practice as a moderating variable on the influence of these two recovery strategies on consumer satisfaction. The results of this study are expected to contribute to the field of service marketing management, especially in developing the theory of service improvement strategies that have been widely researched so far.

\subsection{Research Hypothesis Development}

Service recovery is a variety of actions taken to overcome service failures by the company so that disappointed consumers feel satisfied again (Zeithaml, Bitner, and Grem, 2018). The company can do several strategies: timelines/promptness, facilitation, redress/compensation, apology, credibility, attentiveness/empathy, effort, and reparation (Heidenreich et al., 2015; Li, 2015; Mattila, Cho, and Ro, 2011). 
One of the easiest and cheapest service recovery strategies to do is to apologize. It turns out that an apology can lead to consumer satisfaction if it is done sincerely (Pacheco, Pizzutti, Basso, and Van Vaerenbergh, 2019). In addition to the apology, consumers also expect the company to explain why the failure occurs and what service improvements the company will do. The better the explanation given, the greater the customer satisfaction with the improvements made (Seawright, Bell DeTienne, Preston Bernhisel, and Hoopes Larson, 2008).

These two strategies are considered important in handling service failure because if consumers can accept these strategies, their satisfaction level will increase (Heidenreich et al., 2015; Kazi and Prabhu, 2016; Orsingher, Valentini, and de Angelis, 2010; Pacheco et al., 2019). It is interesting that apologizing, then explaining what caused the problem and explaining improvements made by the company can reduce consumer frustration and even result in consumer satisfaction (Blodgett et al., 2015; Iglesias, Varela-Neira, and VázquezCasielles, 2015; Odoom et al., 2019). Therefore, the hypotheses proposed in this study were:

H1: Apology has a positive influence on recovery satisfaction

$\mathrm{H} 2$ : Explanation has a positive influence on recovery satisfaction

Currently, it is very important to manage the business in a socially responsible manner to stakeholders (Lazar, 2017). Several studies have produced findings regarding the benefits of carrying out business activities concerning the environment; for example, it can increase the desire to make a purchase (Ekasari, 2018) and make consumers more loyal to the company (Assaker, 2020). In addition, when consumers see that the company is environmentally oriented, they are still willing to purchase even though the price of the product or service is more expensive (Pratiwi and Pratomo, 2018; Trivedi, Patel, and Savalia, 2015). In the end, this will increase the company's competitive advantage. (Ulusoy and Barretta, 2016).

Particularly in the hotel business, business management that pays attention to the environment has increased consumer loyalty. As a result, it becomes the strength in the tight competition today (Assaker, 2020; Singjai et al., 2018). One study even found that when there was a conflict between consumers and service providers, companies with good social responsibility and service improvements were easier to produce customer satisfaction. As a result, consumers desire to return to visit the service business (La and Choi, 2019). Based on the results of the above studies, it can be estimated that the implementation of environmentally-conscious operational or green practice is very likely to moderate consumer satisfaction on service improvements provided by the company. The explanation above produced the following hypotheses:

H3: Green practice moderates the influence of apology on recovery satisfaction.

$\mathrm{H} 4$ : Green practice moderates the influence of explanation on recovery satisfaction.

\subsection{Conceptual Framework}

When a business fails to deliver services, consumers will be disappointed, likely leaving the company. It is very important for the company to deliver an apology and explain why the problem occurred and what improvements the company will make to overcome this problem. Both of these strategies are expected to result in customer satisfaction for the improvements made, but this goal cannot necessarily be achieved. One of the variables expected to strengthen (moderate) the influence of the two strategies is green practice. It is expected that consumers will more easily forgive and accept explanations when the hotel used is environmentally conscious. This idea is illustrated in the following framework: 


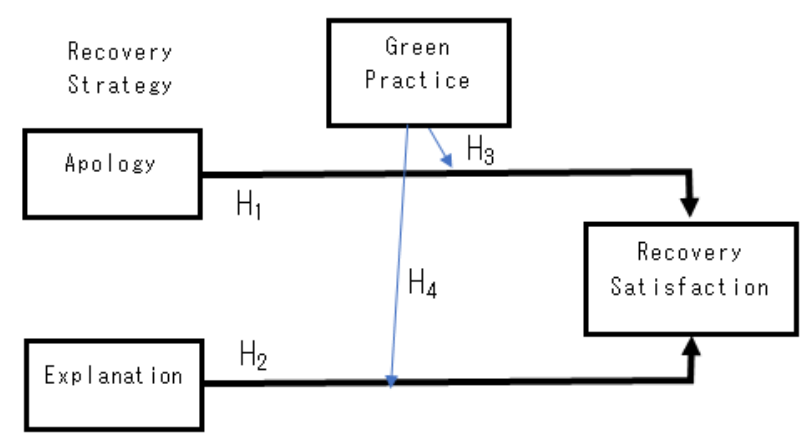

Fig. 1. Research Conceptual Framework

\section{Research Method}

The research design used was hypothesis testing (Sekaran and Bougie, 2016). The analysis units were consumers of green hotels. The data were collected using a cross-sectional method, namely observations carried out at one specific time, from May to July 2021. Sampling was carried out using a non-probability sampling method with a purposive sampling technique (Malhotra, 2015; Sekaran and Bougie, 2016). The criteria determined by the researchers were (1) individuals who have stayed at a green hotel, (2) individuals who have experienced service failure from a green hotel, and (3) individuals who have received service improvements from a green hotel. The minimum number of samples in this study was 30 samples. The ongoing Covid-19 pandemic condition made it difficult for us to obtain representative samples, and as a result, we only obtained 40 respondents. Therefore, this study used the multiple regression analysis method.

The research instruments consisting of apology and explanation variables were measured using eight statement items adapted from Odoom et al. (2019) and Pacheco et al. (2019), recovery satisfaction was measured using three statement items adapted from Odoom et al. (2019), and one moderating variable, namely green practice, was measured using six statement items adapted from Assaker (2020). The validity of the research instruments was tested using Pearson's Correlation, and the reliability of the instruments was tested by looking at the value of Cronbach's Alpha. Based on the validity test results, the final result of the significance value on the four variables was $0.000<0.005$, respectively, indicating that the statement items of all variables were valid. On the other hand, based on Cronbach's alpha, the reliability test of the four variables had a value above 0.6 ; thus, the instruments were concluded as reliable.

\section{Results and Discussion}

\subsection{Classical Assumption Test}

Multiple regression analysis requires several stages of separate testing. Before conducting the multiple regression analysis for testing the research hypothesis, some assumptions or requirements must be met in the regression model. The requirements and assumptions are proven through a series of classical assumption tests, including normality test, multicollinearity test, autocorrelation test and heteroscedasticity test. 


\subsection{Error Normality Test}

The normality test is the distribution of data that is close to the normal distribution. This study uses an approach of exact sig value $>0.05$. The results of the normality test for this study are shown in the following Table 1:

Table 1. Results of Error Normality Test

\begin{tabular}{cc}
\hline One-Sample Kolmogorov-Smirnov Test & Unstandardized Residual \\
\hline Exact Sig. (2-tailed) & .730 \\
\hline Source: Results of data processing using SPSS 25
\end{tabular}

From the table above, the calculation results show an exact sig of $0.973>0.05$. Thus, it can be concluded that the data error is normally distributed. Therefore, the assumption of normality is met.

\subsection{Multicollinearity Test}

The multicollinearity test shows a correlation between two or more independent variables in the multiple regression model. VIF value of $<10$ indicates there is no relationship between the independent variables. Table 2 shows the results of the multicollinearity test in this study:

Table 2. Results of Multicollinearity Test

\begin{tabular}{cc}
\hline Variable & VIF \\
\hline Apology & 47.839 \\
Explanation & 56.303 \\
\hline
\end{tabular}

Source: Results of data processing using SPSS 25 (attached)

The VIF for the Explanation variable is $56.303>10$, which indicates the presence of multicollinearity. It can be concluded that all independent variables, namely apology and explanation contain multicollinearity.

\subsection{Autocorrelation Test}

An autocorrelation test can be done by looking at the Durbin Watson value, which will be compared with the acceptance or rejection criteria made with the $\mathrm{dL}$ and $\mathrm{dU}$ values. The results will be determined based on the number of samples in the regression model and the number of samples in the study. The results of the autocorrelation test for this study is presented in the following Table 3:

Table 3. Results of Autocorrelation Test

$$
\begin{gathered}
\hline \text { Durbin-Watson } \\
\hline 2.346
\end{gathered}
$$

\begin{tabular}{|c|c|c|c|c|c|}
\hline $\begin{array}{l}\text { There is } \\
\text { Positive Auto }\end{array}$ & Inconclusive & No Autocorrelation & Incone & usive & $\begin{array}{l}\text { There is } \\
\text { Negative } \\
\text { Auto }\end{array}$ \\
\hline $\begin{array}{l}0 \\
0\end{array}$ & $\begin{array}{c}\mathrm{dL} \\
1.391\end{array}$ & $\begin{array}{l}\mathrm{dU} \\
1.600\end{array}$ & $\begin{array}{l}4-\mathrm{dU} \\
2.400\end{array}$ & \begin{tabular}{|c|}
$4-\mathrm{dL}$ \\
2.609
\end{tabular} & $\begin{array}{l}4 \\
4\end{array}$ \\
\hline
\end{tabular}

Source: Results of data processing using SPSS 25 (attached) 
From the above calculation results, the Durbin Watson value is 2.346 and is in an area where there is no autocorrelation. It can be concluded that the resulting model is free from autocorrelation problems.

\subsection{Heteroscedasticity Test}

The heteroscedasticity test is a test to see if the data has unequal variance among the group members. The heteroscedasticity test is done by looking at the value of $\operatorname{sig}>0.05$. The results of the heteroscedasticity test can be seen in Table 4 below:

Table 4. Results of Heteroscedasticity Test

\begin{tabular}{cc}
\hline Variable & Sig \\
\hline Apology & 0.188 \\
Explanation & 0.176 \\
\hline
\end{tabular}

Source: Results of data processing using SPSS 25 (attached)

From the results in the table above, the following results can be obtained:

a. The sig value for the apology variable is $0.188>0.05$, which indicates no heteroscedasticity.

b. The sig value for the explanation variable is $0.176>0.05$, which indicates no heteroscedasticity.

From the description above, it can be concluded that the assumption of heteroscedasticity is met since all variables do not contain heteroscedasticity.

\subsection{Descriptive Statistics}

After the four tests above have been carried out, the descriptive statistics are calculated from the observed variables using the mean and standard deviation values. Table 5 shows the result of the descriptive statistics.

Table 5. Results of Descriptive Statistics

\begin{tabular}{ccc}
\hline Variable & Mean & Standard Deviation \\
\hline Apology & 4.256 & 0.844 \\
Explanation & 3.894 & 0.908 \\
Recovery satisfaction & 4.067 & 0.860 \\
Green practice & 4.070 & 1.016 \\
\hline \multicolumn{2}{c}{ Source: Results of data processing using SPSS 25 (attached) }
\end{tabular}

Table 5 confirms that the apology variable has an average value of 4.256 ; this indicates that most respondents thought the hotel apologizes to consumers sincerely. It is evident from consumer perceptions that the hotel showed regret and apologized for the inconvenience felt by visitors. The standard deviation value of 0.848 indicates that the respondents' answers varied. The explanation variable has an average value of 3.894. This value indicates that most respondents think that hotel employees explain well why service failures can occur. It can be seen that most respondents felt that hotel employees could explain well the reasons, the causal factors and also the possibilities for failure to occur. The standard deviation value of 0.908 indicates that the respondents' answers varied. 
The recovery satisfaction variable has an average value of 4.067 , which indicates that most respondents were satisfied with the service improvements made by the hotel for the problems they face. It is evidenced by the perception of visitors who were satisfied with the solutions provided. They were satisfied with the way the hotel handles complaints from visitors. The standard deviation value of 0.860 indicates that the respondents' answers varied.

The last variable is the green practice variable, which has an average value of 4.070. Most respondents thought that the hotel had carried out its operational activities by paying attention to the environment. It is following the opinion of visitors that the hotel had used sensors to turn off the lights when visitors wanted to leave the room, used a card as a key that would function to turn off, and turned on the electricity in the room, used LED lights in the hotel room, provided mineral water in gallons at various hotel rooms, and provided soap and shampoo in dispensers to avoid the use of plastic waste in the hotel environment. The standard deviation value of 1.016 indicates that the respondents' answers varied.

\title{
3.7 Hypothesis Test
}

\section{a) Coefficient of Determination}

The results of the coefficient of determination test should be close to the value of 1 . The results of the determination coefficient test are shown in Table 6 below:

\author{
Table 6. Results of Coefficient of Determination Test \\ Adjusted R Square \\ 0.512 \\ Source: Results of data processing using SPSS 25 (attached)
}

The adjusted R-square value of 0.512 indicates that the variation of the independent variables (apology and explanation) can explain the variation of the dependent variable (recovery satisfaction) by $51.2 \%$. The rest $48.8 \%$ is explained by other independent variables that influence recovery satisfaction but are not included in the research model.

\section{b) Global Test (F Test)}

This analysis is used to determine whether there is a significant relationship or influence of apology and explanation variables on the recovery satisfaction variable. The condition for the equal influence of independent variables is the value of sig should be $<0.05$. Table 7 shows the result of the Global Test.

The null hypothesis and the alternative hypothesis can be stated as follows:

Ho: None of the independent variables (apology and explanation) influences recovery satisfaction.

Ha: There is at least one independent variable that influences the dependent variable.

Table 7. Results of Global Test (F Test)

Source: Results of data processing using SPSS 25 (attached)


From the table above, the sig value is $0.000<0.05$. It can be concluded that there is at least one independent variable (apology and explanation) that influences recovery satisfaction.

\section{c) t-test (Hypothesis Test)}

In the study, the t-test aims to see whether the independent variable individually influences the dependent variable. Table 8 shows the following results:

Table 8. Results of Hypothesis Test

\begin{tabular}{lcccc}
\hline \multicolumn{7}{c}{ Hypothesis } & B & Sig & Result \\
\hline H1: apology has a positive influence on recovery satisfaction & 1.716 & 0.018 & H1 is supported \\
H2: explanation has a positive influence on recovery & - & 0.094 & H2 is not \\
satisfaction & 1.124 & & supported \\
H3: apology has a positive influence on recovery satisfaction & - & 0.060 & H3 is not \\
moderated by green practice & 0.297 & & supported \\
H4: explanation has a positive influence on recovery & 0.355 & 0.042 & H4 is supported \\
satisfaction moderated by green practice & & & &
\end{tabular}

\section{Hypothesis 1}

The first hypothesis examines the influence of Apology on Recovery Satisfaction, where the null hypothesis (Ho) and the alternative hypothesis (Ha) are as follows: Ho1: Apology does not have a positive influence on recovery satisfaction. Ha1: Apology has a positive influence on recovery satisfaction.

Table 11 shows that the $B$ value in the first hypothesis is 1.716 , which theoretically suggests a positive influence between apology and recovery satisfaction. The p-value is 0.018 $<$ alpha 0.05 , which means that statistically there is a significant influence between apology on recovery satisfaction. It is concluded that apology has a significant positive influence on recovery satisfaction.

Thus, the deeper the apology made by the hotel regarding the failure experienced by the customer, the more satisfying the recovery for service failure experienced by the customer will be. When the hotel shows its regret for the problems that have occurred, consumers feel that the hotel has responded to their complaints very well so that they are satisfied with the improvement of hotel services. It supports the framework developed by Abisuga, Wang, and Sunindijo (2020) that apology will increase consumer satisfaction, increase the desire to remain as a consumer, and even convey a positive word of mouth. Apologies can even reduce the consumer's desire to continue the complaint (Iglesias et al., 2015).

\section{Hypothesis 2}

The second hypothesis examines the influence of explanation on recovery satisfaction, where the null hypothesis (Ho) and the alternative hypothesis (Ha) are as follows:

Ho2: Explanation does not have a positive influence on recovery satisfaction.

$\mathrm{Ha} 2$ : Explanation has a positive influence on recovery satisfaction.

Table 11 shows that the $\mathrm{B}$ value in the second hypothesis is -1.124 , which means that there is a negative influence between explanation on recovery satisfaction (which does not pass the theory test). The p-value is $0.094>$ alpha 0.05 , which means that statistically, there is no 
significant influence between explanation on recovery satisfaction. Thus, it can be concluded that there is no positive influence between explanation on recovery satisfaction.

It shows that although the hotel has tried to explain to consumers what caused the service failure, it turns out that consumers are still dissatisfied with the service improvements made. Although the results of this study do not support research conducted by Odoom et al. (2019), it turns out that Iglesias et al. (2015) show that explanations do not succeed in satisfying consumers.

\section{Hypothesis 3}

The third hypothesis examines the influence of Apology on Recovery Satisfaction moderated by Green Practice, where the null hypothesis (Ho) and the alternative hypothesis (Ha) are as follows:

Ho3: Apology does not have a positive influence on Recovery Satisfaction moderated by Green Practice.

Ha3: Apology has a positive influence on Recovery Satisfaction moderated by Green Practice.

Table 11 shows that the $\mathrm{B}$ value in the third hypothesis is -0.297 , which means a negative influence between apology and recovery satisfaction moderated by green practice. The p-value is $0.060>$ alpha 0.05 , which means that statistically, there is no significant influence between apology on recovery satisfaction moderated by green practice. Thus, the conclusion is that green practice does not have a moderating role in influencing apology on recovery satisfaction.

It shows that consumers who have chosen green hotels are not more satisfied with the hotel's apology. For consumers, the position as a green hotel does not make them more satisfied when the hotel apologizes for the failure.

\section{Hypothesis 4}

The fourth hypothesis examines the influence of explanation on recovery satisfaction moderated by green practice, where the null hypothesis (Ho) and the alternative hypothesis (Ha) are as follows:

Ho4: Explanation does not have a positive influence on recovery satisfaction moderated by green practice.

Ha4: Explanation has a positive influence on recovery satisfaction moderated by green practice.

Table 11 shows that the $\mathrm{B}$ value in the fourth hypothesis is 0.355 , which means that theoretically, there is a positive influence between explanation on recovery satisfaction moderated by green practice. The p-value is $0.042<$ alpha 0.05 , which means that statistically, there is a significant influence between explanation on recovery satisfaction moderated by green practice. Thus, it can be concluded that green practice has a moderating role in influencing explanation on recovery satisfaction.

Therefore, it can be said that green practice will strengthen or weaken the influence of explanation on recovery satisfaction. It shows that consumers who choose to stay at green hotels can finally accept an explanation from the hotel for the failure. 


\section{Conclusions}

Based on the study results, it can be concluded that apology has a positive influence on recovery satisfaction, but it does not have an influence when moderated by green practice. On the other hand, explanation does not influence recovery satisfaction, but it does influence when moderated by green practice.

\section{Managerial Implications}

This study concludes the important role of apology in generating customer satisfaction for service improvements. The hotel needs to improve the hotel employees' ability to convey a sincere apology. For this reason, it is necessary to conduct training for hotel employees in conducting service encounters to show their sincerity in interacting with consumers. Explanation also has a strong influence when moderated by green practice. Therefore, the hotel must improve the ability of its employees to provide good explanations, especially those related to environmentally-conscious practices carried out by the company. Finally, hotels should strengthen various environmentally-conscious operational activities so that visitors can immediately feel an environmentally-conscious ambience while staying.

\section{Limitations and suggestions}

Respondents in this study are limited to environmentally-conscious hotel visitors. This particular selection of respondents makes it difficult to obtain respondents. For this reason, it is recommended for further research to look for service businesses that have become very popular during the Covid-19 pandemic, such as marketplaces. Furthermore, this study limits the service recovery strategies on apology and explanation, and only examines green practice as a moderating variable. For this reason, it is necessary to research various other service recovery strategies that might influence customer satisfaction, such as speed, effort and compensation (Ibok, Umana, and Agu, 2012).

\section{References}

[1] Abisuga, A. O., Wang, C. C., and Sunindijo, R. Y.: Facility managers' responses to user post-occupancy feedback: a conceptual framework. Facilities, 38(7-8), 481-499 (2020). https://doi.org/10.1108/F-10-2018-0119

[2] Assaker, G.: The effects of hotel green business practices on consumers' loyalty intentions: an expanded multidimensional service model in the upscale segment. International Journal of Contemporary Hospitality Management, 13(12), 3787-3807 (2020). https://doi.org/10.1108/IJCHM-05-2020-0461

[3] Azemi, Y., Ozuem, W., Howell, K. E., and Lancaster, G.: An exploration into the practice of online service failure and recovery strategies in the Balkans. Journal of Business Research, 94(September 2018), 420-431 (2019). https://doi.org/10.1016/j.jbusres.2018.08.035

[4] Blodgett, J., Bakir, A., Saklani, A., and Bachheti, M.: Customer Complaint Behavior: an Examination of Cultural Vs. Situational Factors. Journal of Consumer Satisfaction/Dissatisfaction and Complaining Behavior, 28, 61-74 (2015)

[5] Chou, C., Hsu, Y. H., and Goo, Y. J.: Service failures and recovery strategies from the 
service provider perspective. Asia Pacific Management Review, 14(2), 237-249 (2009)

[6] Ekasari, A.: Pengaruh Drive for Environmental Responsibility, Collectivism Dan Subjective Norm Terhadap Behavioral Intention Penggunaan Reusable Bag. Manajemen Dan Pemasaran Jasa, 11(2), 201-216 (2018)

[7] Ellyawati, J., Purwanto, B., and Dharmmesta, B.: The Effect Of Perceived Justice On Customer Satisfaction In The Service Recovery Context: Testing Mediating Variables. Journal of Service Science, 5(2), 87-100 (2012). Retrieved from http://search.ebscohost.com/login.aspx?direct=trueandprofile=ehostandscope=siteanda uthtype $=$ crawlerandjrnl $=19414722$ andAN=93479800andh $=$ ccopBnESDxdvnQaL5OV N9dTMKxu6nST/klaYNWHJTotoOaO615bWE5Sf1qDOOQHDaTreIqX+8b4zeSgQO $\mathrm{jE} 7 \mathrm{Hg}==\mathrm{and} \mathrm{crl}=\mathrm{c}$

[8] Erlangga, T. F., Rahmafitria, F., and Rosita: Analisis Perbandingan Tamu Manca. Jurnal Manajemen Resort Dan Leisure, 13(2), 103-118 (2016)

[9] Grégoire, Y., and Fisher, R. J.: Customer betrayal and retaliation: When your best customers become your worst enemies. Journal of the Academy of Marketing Science, 36(2), 247-261 (2008). https://doi.org/10.1007/s11747-007-0054-0

[10] Gruber, T., and Frugone, F.: Uncovering the desired qualities and behaviours of general practitioners (GPs) during medical (service recovery) encounters. Journal of Service Management, 22(4), 491-521 (2011). https://doi.org/10.1108/09564231111155097

[11] Harun, A., Rokonuzzaman, M., Prybutok, G., and Prybutok, V. R.: How to influence consumer mindset: A perspective from service recovery. Journal of Retailing and $\begin{array}{llll}\text { Consumer } & \text { Services, } & \text { 42(February), } & \text { 65-77 }\end{array}$ https://doi.org/10.1016/j.jretconser.2018.01.012

[12] Harun, A., Rokonuzzaman, M., Prybutok, G., and Prybutok, V. R.: Determinants of banking consumers' engagement in post service failure positive word-of-mouth: Examining mediating mechanisms. International Journal of Bank Marketing, 37(2), 621-645 (2019). https://doi.org/10.1108/IJBM-01-2018-0001

[13] Heidenreich, S., Wittkowski, K., Handrich, M., and Falk, T.: The dark side of customer co-creation: exploring the consequences of failed co-created services. Journal of the Academy of Marketing Science, 43(3), 279-296 (2015). https://doi.org/10.1007/s11747-014-0387-4

[14] Ibok, N., Umana, S., and Agu, G.: Investigating the Relative Importance of Customer Recovery Strategies in the Hospitality Industry. Canadian Social Science, 8(6), 8056 (2012). https://doi.org/10.3968/j.css.1923669720120806.3121

[15] Iglesias, V., Varela-Neira, C., and Vázquez-Casielles, R. (2015). Why didn’t it work out? The effects of attributions on the efficacy of recovery strategies. Journal of Service Theory and Practice, 25(6), 700-724. https://doi.org/10.1108/JSTP-04-20140073

[16] Kazi, R., and Prabhu, S.: Literature Review of Service Failure , Service Recovery and their Effects on Consumers and Service Employees. Telecom Business Review, 9(1), 39-45 (2016)

[17] La, S., and Choi, B.: Perceived justice and CSR after service recovery. Journal of Services Marketing, 33(2), 206-219 (2019). https://doi.org/10.1108/JSM-10-20170342

[18] Lazar, C. I.: Perspectives on green marketing and green businesses for sustainable develo...: Economic Sciences, 10(59), 45-79 (2017). Retrieved from http://web.b.ebscohost.com/ehost/pdfviewer/pdfviewer?vid=20andsid=efb310b7-0ecf4c06-9eeb-5b299c3e6c9e\%40pdc-v-sessmgr01 
[19] Li, C.-Y.: Switching barriers and customer retention. Journal of Service Theory and Practice, 25(4), 370-393 (2015). https://doi.org/10.1108/JSTP-10-2013-0220

[20] Malhotra, N. K.: Essentials of Marketing Reasearch: A Hands-On Orientation (Global ed.). Pearson Education Limited, Edinburgh Gate, Harlow - England (2015)

[21] Mattila, A. S., Cho, W., and Ro, H.: The role of self-service technologies in restoring justice. Journal of Business Research, 64(4), 348-355 (2011). https://doi.org/10.1016/j.jbusres.2010.02.014

[22] Moliner-Velázquez, B., Ruiz-Molina, M. E., and Fayos-Gardó, T.: Satisfaction with service recovery: moderating effect of age in word-of-mouth. Journal of Consumer Marketing, 32(6), 470-484 (2015). https://doi.org/10.1108/JCM-12-2014-1251

[23] Moser, A. K.: Thinking green, buying green? Drivers of pro - Environmental purchasing behavior. Journal of Consumer Marketing, 32(3), 167-175 (2015). https://doi.org/10.1108/JCM-10-2014-1179

[24] Odoom, R., Agbemabiese, G. C., and Hinson, R. E.: Service recovery satisfaction in offline and online experiences. Marketing Intelligence and Planning, 38(1), 1-14 (2019). https://doi.org/10.1108/MIP-09-2018-0422

[25] Orsingher, C., Valentini, S., and de Angelis, M.: A meta-analysis of satisfaction with complaint handling in services. Journal of the Academy of Marketing Science, 38(2), 169-186 (2010). https://doi.org/10.1007/s11747-009-0155-z

[26] Pacheco, N. A., Pizzutti, C., Basso, K., and Van Vaerenbergh, Y.: Trust recovery tactics after double deviation: better sooner than later? Journal of Service Management, 30(1), 2-22 (2019). https://doi.org/10.1108/JOSM-02-2017-0056

[27] Pratiwi, S. I., and Pratomo, L. A.: Antecedents of willingness to pay for green products. IOP Conference Series: Earth and Environmental Science, 106(1) (2018). https://doi.org/10.1088/1755-1315/106/1/012093

[28] Rosenbaum, M. S., and Wong, I. A.: Green marketing programs as strategic initiatives in hospitality. Journal of Services Marketing, 29(2), 81-92 (2015). https://doi.org/10.1108/JSM-07-2013-0167

[29] Seawright, K. K., Bell DeTienne, K., Preston Bernhisel, M., and Hoopes Larson, C. L.. An empirical examination of service recovery design. Marketing Intelligence and Planning, 26(3), 253-274 (2008). https://doi.org/10.1108/02634500810871320

[30] Sekaran, U., and Bougie, R.: Research Methods for Bussiness A Skill-Bulding Approach (2016). Retrieved from www.wiley.com

[31] Setiawati, C. I., and Sitorus, P.: Keberhasilan hotel berwawasan ramah lingkungan di Asia-Pasifik: faktor pendorong apakah yang dominan? Jurnal Siasat Bisnis, 18(1), 4562 (2014). https://doi.org/10.20885/jsb.vol18.iss1.art5

[32] Siddiqui, M. H., and Tripathi, S. N.: An analytical study of complaining attitudes: With reference to the banking sector. Journal of Targeting, Measurement and Analysis for Marketing, 18(2), 119-137 (2010). https://doi.org/10.1057/jt.2010.2

[33] Singjai, K., Winata, L., and Kummer, T. F.: Green initiatives and their competitive advantage for the hotel industry in developing countries. International Journal of Hospitality Management, 75(September 2017), 131-143 (2018). https://doi.org/10.1016/j.ijhm.2018.03.007

[34] Song, S., Sheinin, D. A., and Yoon, S.: When women are dissatisfied: Gender differences in product failure attribution. Social Behavior and Personality: An International Journal, 45(8), 1397-1408 (2017). https://doi.org/10.2224/sbp.6169

[35] Supriadi, B.: Investigasi Green Hotel Sebagai Alternatif Produk Ramah Lingkungan. In Seminar Nasional Inovasi dan aplikasi Teknologi di Industri (SENIATI) pp. 10-19 
(2016).

[36] Trivedi, R. H., Patel, J. D., and Savalia, J. R.: Pro-environmental behaviour, locus of control and willingness to pay for environmental friendly products. Marketing Intelligence and Planning, 33(1), 67-89 (2015). https://doi.org/10.1108/MIP-03-20120028

[37] Ulusoy, E., and Barretta, P. G.: How green are you, really? Consumers' skepticism toward brands with green claims. Journal of Global Responsibility, 7(1), 72-83 (2016). https://doi.org/10.1108/JGR-11-2015-0021

[38] Wang, C., and Mattila, A. S.: A cross-cultural comparison of perceived informational fairness with service failure explanations. Journal of Services Marketing, 25(6), 429439 (2011). https://doi.org/10.1108/08876041111161023

[39] Weun, S., Beatty, S. E., and Jones, M. A.: The impact of service failure severity on service recovery evaluations andpost-recovery relationships. Journal of Services Marketing, 18(2), 133-146 (2004). https://doi.org/10.1108/08876040410528737

[40] Yani-de-Soriano, M., Hanel, P. H. P., Vazquez-Carrasco, R., Cambra-Fierro, J., Wilson, A., and Centeno, E.: Investigating the role of customers' perceptions of employee effort and justice in service recovery: A cross-cultural perspective. European Journal of Marketing, 53(4), 708-732 (2019). https://doi.org/10.1108/EJM-09-20170570

[41] Zeithaml, V. A., Bitner, M. J., and Grem.: Services Marketing : Integrating Customer Focus Across the Firm. McGraw Hill Education (7th ed.). New York: McGraw-Hill Education, New York, NY (2018). https://doi.org/10.1016/j.bushor.2008.01.008 